\title{
Future Fertiliser Demand and Role of Organic Fertiliser for Sustainable Rice Production in Bangladesh
}

\author{
Jayanta Kumar Basak ${ }^{1}$, Rashed Al Mahmud Titumir², Khosrul Alam \\ ${ }^{1}$ Department of Environmental Science and Hazard Studies, Noakhali Science and Technology University, Noakhali, Bangladesh \\ ${ }^{2}$ Department of Development Studies, University of Dhaka, Dhaka, Bangladesh \\ ${ }^{3}$ Department of Economics, Noakhali Science and Technology University, Noakhali, Bangladesh
}

\section{Email address:}

basak.jkb@gmail.com (J. K. Basak),rtitumir@unnayan.org (R. A. M. Titumir), alam.khosrul@gmail.com (K. Alam)

\section{To cite this article:}

Jayanta Kumar Basak, Rashed Al Mahmud Titumir, Khosrul Alam. Future Fertiliser Demand and Role of Organic Fertiliser for Sustainable Rice Production in Bangladesh. Agriculture, Forestry and Fisheries. Vol. 4, No. 5, 2015, pp. 200-208. doi: 10.11648/j.aff.20150405.11

\begin{abstract}
The study finds out the requirement of chemical fertilisers and suggests the role of organic fertilisers for sustainable rice production based upon projection of rice production, consumption, demand and supply of fertilisers for the years of 2020, 2030, 2040 and 2050. The total requirement for commonly used three fertilisers, Urea, Triple Supper Phosphate (TSP) and Muriate of Potash (MP) may increase significantly due to compulsions for growing increased amount of crop outputs in small fragmented parcels of land in the context of diminishing cultivable lands in Bangladesh, negatively impacting on soil fertility as well as sustainability of crop production. Since sustainable yield of crop considerably depends on balanced application of both chemical and organic fertilisers in the field level, the research suggests for increased usage of organic fertilisers.
\end{abstract}

Keywords: Rice, Fertilisers, Organic Fertilisers, Urea, TSP, MP

\section{Introduction}

Balanced fertilisation is a key factor for sustainable crop production. Sustainable agriculture practice is being hampered persistently due to decreased soil fertility arising out of inappropriate application of fertilisers. This is particularly important for the agriculture of Bangladesh as the country faces compulsion for growing more food to feed its sizeable population in the backdrop of diminishing cultivable land areas due to pressures stemming from increased population, habitation, industrialisation and urbanisation. Therefore, a well-thought-out strategy on balanced mix of fertilisers should receive a top priority to sustain or increase the level of production of crops.

In recent years, agricultural sector in Bangladesh has been facing a twofold major challenge of producing more food in limited lands to meet the food demand for its huge population along with keeping food prices within an accessible limit for the poor to ensure food security on the one hand, and of minimising the adverse environmental impacts to maintain a sustained level of production and profitability for the peasants along with sound conservation of resource, on the other.
Sustainable agriculture involves the processes that would enable to meet the current and long term societal needs for food, fiber and other resources optimising the benefits through conservation of natural resources and maintenance of ecosystem. Sustainable agricultural practices have to strike a balance between environmental health and economic profitability in order to promote social and economic equity [1]. Therefore, the stewardship of both natural and human resources is of prime importance. The priority of enhancing human capabilities at the individual (peasant-farmer) level and ensuring food security at the national level through efficient and equitable use of resources are compatible with the concept of sustainable agriculture. In order to strike stability between safeguarding environmental components and increased agricultural productivity, it is necessary to promote not only the use of chemical fertilisers but also usage of organic fertilisers in a balanced way.

Before the 1950's, the peasant-farmers of Bangladesh used to apply organic manures such as cow dung, bone meal etc. in aus and aman rice fields and farmyard manure (FYM), mustard oil cake and fishmeal for the mustard and vegetable 
crops [2]. The use of inorganic fertiliser started in the country in 1951 with the import of 2,698 tons of Ammonium Sulphate, Phosphates in 1957 and Muriate of Potash in 1960 [3]. The fertiliser was introduced at farm level in 1959 [4]. Then, in 1965, the Government launched a 'Grow More Food' campaign and provided fertilisers and low lift pump (LLP) at a highly subsidised rate with pesticide at free of cost to popularise these inputs among the peasants to meet the country's food shortage. Thus, fertiliser consumption began to increase rapidly with the introduction of HYV rice (i.e. IR5 \& IR8) and use of LLPs. Now-a-days, chemical fertilisers consists of more than 75 percent of total fertilisers used for rice production [5].

A number of studies have been conducted on sustainability in agricultural sector in Bangladesh [6], [7], [8], [9], [10], [11], [12], [13], and [14]. Most of these studies, however investigated the changes in rice yield under different treatment of fertilisers by various doses in the experiment fields. It is also studied on strategies for developing the fertiliser sector in Bangladesh for sustainable agriculture [15], [16]. The farmers of Bangladesh mostly rely on chemical fertilisers for higher production, without or less application of compost. Such a fertiliser management practice leaves a massive deterioration of soil fertility, resulting loss in organic content [16].

The present research estimates requirement of chemical fertilisers and focuses on the role of organic fertiliser in sustainable rice production in Bangladesh. The estimation has relied on the different published accounts released by the Bangladesh Bureau of Statistics (BBS) and Ministry of Agriculture (MOA) such as Handbook of Agricultural Statistics and Statistical Year Book of Bangladesh [17], [18],
[19], [20], [21].

\section{Contribution of Fertilisers to Crop Production in Bangladesh}

Crop nutrients are the elements, or simple inorganic compounds, indispensable for the growth of crops. For rice production, 16 elements are essential - Carbon, Hydrogen, Oxygen, Nitrogen, Phosphorus, Potassium, Sulfur, Calcium, Magnesium, Zinc, Iron, Copper, Molybdenum, Boron, Manganese and Chlorine. All essential elements are required in optimum amounts and usable forms for rice plants. Nitrogen, Phosphorus, Zinc and Potassium are the most commonly applied nutrient elements in rice fields whereas Sulfur is occasionally used on the basis of soil condition and other nutrients are provided by air, water, soil and plant residues [22].

Chemical fertiliser provides the nutrient elements (Nitrogen, Phosphorus, Zinc and Potassium) for soils and plays the most vital role in crop production. It supports half of the world's grain production [23]. The contribution of fertilisers in rice production was 40 percent [24]. Results of long-term experiments conducted by Bangladesh Rice Research Institute (BRRI) also shows that fertilisers provide for 36-40 percent nutrient in rice cultivation (averaged over Boro and T. Aman crops during 1985-86 to 2006-07). In 1985-86, fertiliser has contributed 36 percent to the total soil fertility whereas in 2002-07, this percentage was 40 (Figure 1) [25]. Thus, the increasing use of fertilisers over time also indicates the degradation of soil fertility.

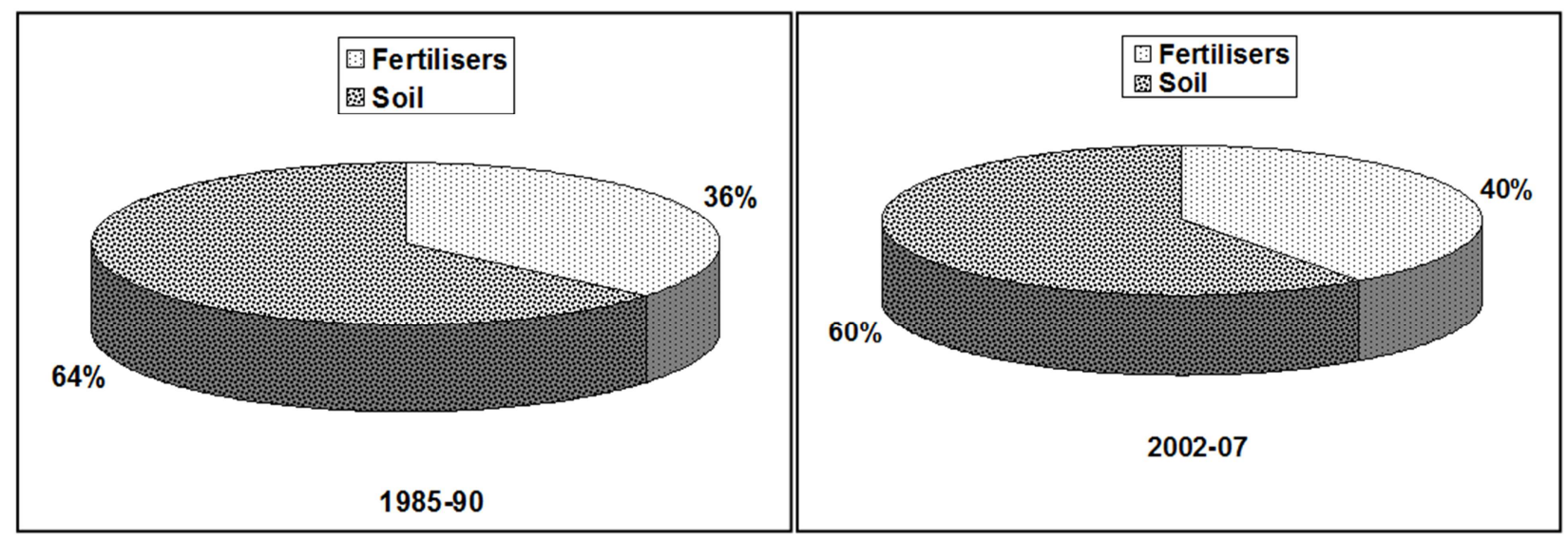

Source: Shah et al., 2008

Figure 1. Percentage of contribution in soil and fertiliser in rice yield in 1985-90 and 2002-07.

\section{Demand of Fertilisers in Bangladesh}

Fertiliser application mainly depends on the soil types, growing season, irrigation and the varieties that are used. The demand for fertiliser is also affected by the agro-climatic conditions. High yielding varieties (HYV) of rice are highly responsive and need adequate amount of fertiliser to achieve the targeted production.

The use of chemical fertilisers in Bangladesh has amplified sharply after 1975. Consumption of significant amount of chemical fertiliser was noted during 1975-76. Since then, ever-increasing trend of usage of fertilisers has been observed which reached at peak value of 36.50 lakh tons during 2007-08 (Figure 2). Along with Urea, TSP and MP, the use of Gypsum, Zinc Sulphate and other 
micronutrients also augmented after the period of 1975-76.

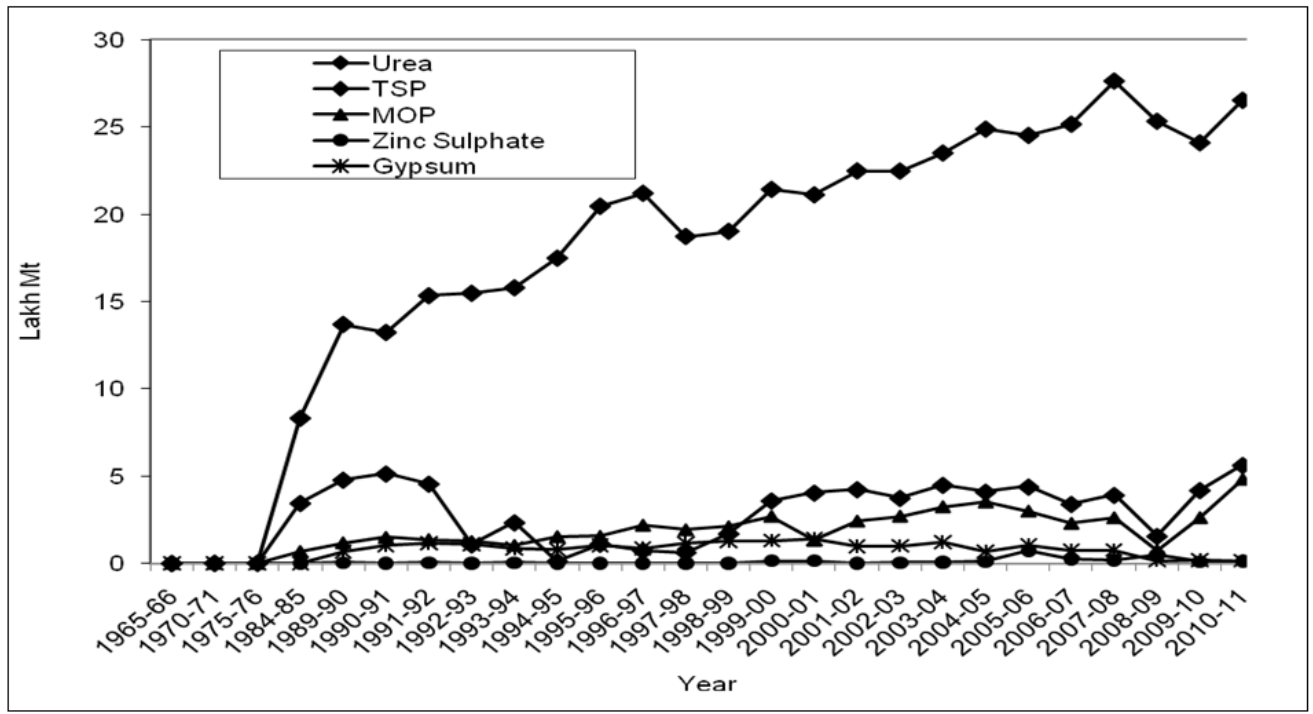

Source: Authors' calculation based on Bangladesh Fertiliser Association (BFA) data, 2009 and Bangladesh Economic Review, 2013

Figure 2. Consumption of different fertilisers in Bangladesh (year wise).

Table 1. Comparative land use under rice production of different varieties.

\begin{tabular}{llll}
\hline \multirow{2}{*}{ Seasons } & \multicolumn{3}{l}{ Percentage of Area Coverage } \\
\cline { 2 - 4 } & Local varieties & HYV & Hybrid \\
\hline Aus & 28.67 & 71.33 & 0.00 \\
Aman & 32.11 & 67.89 & 0.00 \\
Boro & 2.29 & 78.56 & 19.16 \\
Total & 19.79 & 72.55 & 7.66 \\
\hline
\end{tabular}

Source: Department of Agriculture Extension, 2008-09

The rate of application of urea is significantly higher compared to other fertilisers for cultivating high yielding rice varieties. Before 1975-76, most of the peasants cultivated traditional varieties and used organic manures such as cow dung, bone meal etc. The irrigated area of rice has dramatically increased and a large portion of cultivable land has been covered under minor irrigation project. In the irrigated condition, farmers cultivate HYV rice, which requires high fertiliser dose compared to the local varieties.

In 2008-09, HYVs covered more than 72 percent to the total cultivable land areas in Bangladesh (Table 1). Therefore, a large amount of fertiliser is being used to cultivate HYVs. Consequently, the demand of chemical fertilisers follows an increasing trend year after year. Like greater use of HYVs, cropping intensity has also influenced fertiliser application over the years. Cropping intensity has increased dramatically in the last decades. In 1980, the cropping intensity was 153.74 percent and intensity moved upward to reach at 176.91 in 2004-05. The Department of Agriculture Extension (DAE) claims that the current cropping intensity is 195 percent. Therefore, cropping intensity increased more than 23 percent in 15 years (1980-81 to 2004-05) (Figure 3).

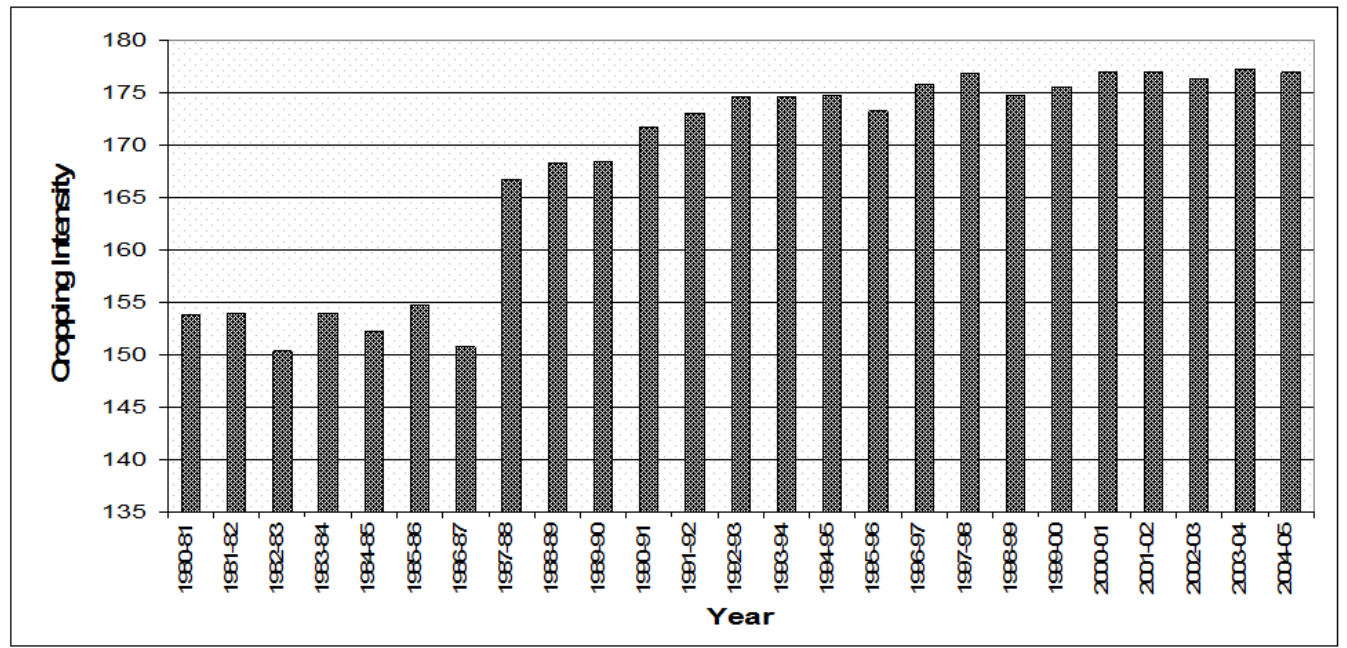

Source: Handbook of Agricultural Statistics, Ministry of Agriculture, 2013

Figure 3. Cropping intensity over time in Bangladesh, 1980-81 to 2004-05 (percentage). 


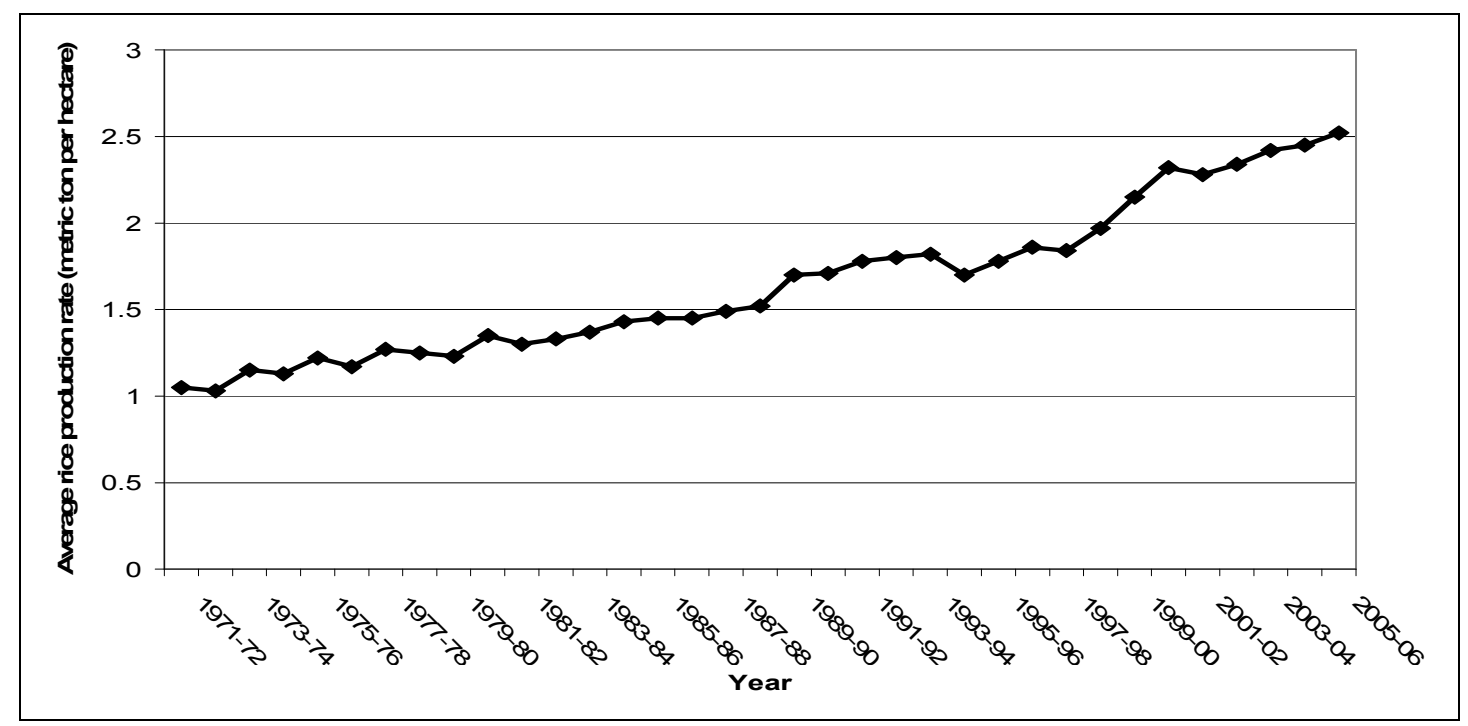

Source: Handbook of Agricultural Statistics, Ministry of Agriculture, 2013

Figure 4. Average yield of rice from 1971-72 to 2005-06 (season wise).

By analyzing the rice yield data for 35 years (1971-72 to $2005-06)$, it is found that rate of rice production is continuously increasing over the years. In 1971-72, the average rice yield was 1.05 metric ton per hectare and reached at 2.52 metric ton per hectare in 2005-06. Therefore, average rice yield increased 2.4 times in 35 years and the increased use of fertiliser has significantly influenced the yield. For instance, in Bangladesh, application of fertilisers increased several times in the same piece of land. In 1975-76, fertiliser application was $0.36 \mathrm{~kg}$ per hectare in agricultural land, whereas in 2007, this application was above $298 \mathrm{~kg}$ per hectare [26].

\section{Future Requirement of Fertilisers in Rice Production}

The amounts of recommended and actual dose of fertilisers for rice production in Bangladesh are given in Table 2. Urea (Nitrogen) is a major component of proteins, hormones, chlorophyll, vitamins and enzymes and is essential for rice. Rice plants require a large amount of nitrogen at the early and mid-tillering stages to maximise the number of panicles [22]. The recommended doses of other nutrients are also necessary for a potential rice yield.

Table 2. Use of fertilisers in Bangladesh.

\begin{tabular}{|c|c|c|c|c|c|c|c|c|c|}
\hline \multirow[t]{2}{*}{ Name of Crop (HYV) } & \multicolumn{3}{|c|}{ Recommended dose (kg/ha) } & \multicolumn{3}{|c|}{ Actual dose (kg/ha) } & \multicolumn{3}{|c|}{ Use gap (percentage) } \\
\hline & Urea & TSP & MP & Urea & TSP & MP & Urea & TSP & MP \\
\hline T.Aus & 141 & 101 & 69 & 135 & 28 & 17 & 4.26 & 72.28 & 75.36 \\
\hline T.Aman & 166 & 101 & 69 & 135 & 30 & 24 & 18.67 & 70.30 & 65.22 \\
\hline Boro & 269 & 131 & 121 & 192 & 47 & 37 & 28.62 & 64.12 & 69.42 \\
\hline
\end{tabular}

Source: Handbook of Agricultural Statistics, Ministry of Agriculture, 2013

It is estimated that the total population in Bangladesh may stand at 191.65 million by $2020,220.24$ million by 2030 , 253.09 million by 2040 and 290.83 million by 2050 . If the annual population growth continues at a business as usual rate (1.4 percent annually), huge amount of food will be needed to meet demands of the future generations while it is assumed that a major part of the demand will be met by rice. Based upon the data of the last 40 years, the per capita rice consumption rate in Bangladesh is $153.02 \mathrm{~kg}$ per person per year. If the current rice consumption rate continues, the total demand for rice may reach at 68.09 million tons in 2050 (Table-3).

Table 3. Year-wise paddy rice demand in Bangladesh (average).

\begin{tabular}{|c|c|c|c|c|c|}
\hline Year & Population (million) & Paddy rice required (million tons) & Boro rice (million tons) & T.Aman rice (million tons) & Aus rice (million tons) \\
\hline 2007 & 157.75 & 36.93 & 19.20 & 15.14 & 2.59 \\
\hline 2020 & 191.65 & 44.87 & 23.33 & 18.40 & 3.14 \\
\hline 2030 & 220.24 & 51.56 & 26.81 & 21.14 & 3.61 \\
\hline 2050 & 290.83 & 68.09 & 35.41 & 27.92 & 4.77 \\
\hline
\end{tabular}

Source: Authors' calculation based on data of World Bank and Food and Agriculture Organization (Update as of July, 2009 [27])

Population data in 2007 are taken from World Bank data, 2009

Rice consumption rate is calculated from the last 40 years data (1964 -2003) 
The ten-year data (1999-2000 to 2008-09) state that Boro rice contributes 52 percent to the total rice production in Bangladesh, while the contribution of T.aman is 41 percent and $A u s$ is only 7 percent. If the averaged rates of production of Boro, T.aman and Aus are considered, the total rice demand of Boro, T.aman and Aus stands at 35.41, 27.92 and 4.77 million tons respectively in 2050 (Table 3).
As per the business as usual scenario, Boro rice may contribute 59 percent in $2020,60.5$ percent, 61.5 percent and 63 percent in 2030, 2040 and 2050 respectively. Contribution of T.aman may be 34 percent, 33 percent, 32 percent, 31 percent respectively and $A u s$ may be 7 percent, 6.5 percent, 6.5 percent, 6 percent respectively for the corresponding years $($ Table -4$)$.

Table 4. Year-wise paddy rice demand in Bangladesh (changing condition).

\begin{tabular}{llllll}
\hline Year & Population (million) & Paddy rice required (million tons) & Boro rice (million tons) & T.Aman rice (million tons) & Aus rice (million tons) \\
\hline 2007 & 157.75 & 36.93 & 19.20 & 15.14 & 2.59 \\
2020 & 191.65 & 44.87 & 26.47 & 15.26 & 3.14 \\
2030 & 220.24 & 51.56 & 31.19 & 17.01 & 3.35 \\
2040 & 253.09 & 59.25 & 36.44 & 18.96 & 3.85 \\
2050 & 290.83 & 68.09 & 42.90 & 21.11 & 4.09 \\
\hline
\end{tabular}

Source: Authors' calculation based on last 10 years data of Bangladesh Bureau of Statistics, 2012

The total requirement of fertilisers has been estimated on the basis of recommended dose and actual dose of fertilisers applied by the peasants. Average rice production data for the last 10 years and the changing trends of production of Boro, T.aman and Aus for the same period have also been considered. Moreover, yield of Boro, T.aman and Aus is kept constant and other factors such as irrigation management, climatic conditions, varieties etc. are also assumed unchanged to estimate the requirement of fertilisers for the specified years.

According to the fertiliser recommended dose, requirement of Urea is 39.17 lakh tons, TSP 21.77 lakh tons and MP 17.13 lakh tons (calculation based on average rice production data) in 2050 (Table 5). On the basis of trend line analysis of rice production data, requirement of Urea stands at 38.58 lakh tons in 2050, while 20.89 lakh tons of TSP and 17.02 lakh tons of MP may be required for the same year (calculation is based on recommended dose) (Table 6).

Considering the actual dose applied in the field level, the total demand of Urea, TSP and MP in 2050 might be 30.40, 7.01 and 5.45 lakh tons, respectively (calculation based on average rice production data) (Table 7). On the basis of trend line analysis of rice production, requirement of Urea, TSP and MP might be 29.47, 6.88 and 5.35 lakh tons in 2050, correspondingly (Table 8).

Table 5. Requirement of fertiliser on the basis of recommended dose (based on average rice production data).

\begin{tabular}{|c|c|c|c|c|c|c|c|c|c|c|c|c|}
\hline \multirow{2}{*}{ Year } & \multicolumn{3}{|c|}{$\begin{array}{l}\text { Urea fertiliser } \\
\text { requirement (lakh tons) }\end{array}$} & \multirow{2}{*}{$\begin{array}{l}\text { Total } \\
\text { (lakh tons) }\end{array}$} & \multicolumn{3}{|c|}{$\begin{array}{l}\text { TSP fertiliser requirement } \\
\text { (lakh tons) }\end{array}$} & \multirow{2}{*}{$\begin{array}{l}\text { Total } \\
\text { (lakh tons) }\end{array}$} & \multicolumn{3}{|c|}{$\begin{array}{l}\text { MP fertiliser requirement } \\
\text { (lakh tons) }\end{array}$} & \multirow{2}{*}{$\begin{array}{l}\text { Total } \\
\text { (lakh tons) }\end{array}$} \\
\hline & Boro & Aus & Aman & & Boro & Aus & Aman & & Boro & Aus & Aman & \\
\hline 2007 & 10.33 & 1.58 & 9.31 & 21.22 & 5.03 & 1.14 & 5.66 & 11.83 & 4.65 & 0.78 & 3.87 & 9.3 \\
\hline 2020 & 12.55 & 1.93 & 11.3 & 25.78 & 6.11 & 1.38 & 6.88 & 14.37 & 5.65 & 0.94 & 4.7 & 11.29 \\
\hline 2030 & 14.42 & 2.21 & 13 & 29.63 & 7.02 & 1.58 & 7.91 & 16.51 & 6.49 & 1.08 & 5.4 & 12.97 \\
\hline 2050 & 19.05 & 2.92 & 17.2 & 39.17 & 9.28 & 2.09 & 10.4 & 21.77 & 8.57 & 1.43 & 7.13 & 17.13 \\
\hline
\end{tabular}

Source: Authors' calculation based on Ministry of Agriculture and Bangladesh Bureau of Statistics, 2012

Table 6. Requirement of fertiliser on the basis of recommended dose (on changing conditions).

\begin{tabular}{|c|c|c|c|c|c|c|c|c|c|c|c|c|}
\hline \multirow[t]{2}{*}{ Year } & \multicolumn{3}{|c|}{$\begin{array}{l}\text { Urea fertiliser } \\
\text { requirement (lakh tons) }\end{array}$} & \multirow{2}{*}{$\begin{array}{l}\text { Total } \\
\text { (lakh tons) }\end{array}$} & \multicolumn{3}{|c|}{$\begin{array}{l}\text { TSP fertiliser } \\
\text { requirement (lakh tons) }\end{array}$} & \multirow{2}{*}{$\begin{array}{l}\text { Total } \\
\text { (lakh tons) }\end{array}$} & \multicolumn{3}{|c|}{$\begin{array}{l}\text { MP fertiliser requirement } \\
\text { (lakh tons) }\end{array}$} & \multirow{2}{*}{$\begin{array}{l}\text { Total } \\
\text { (lakh tons) }\end{array}$} \\
\hline & Boro & Aus & Aman & & Boro & Aus & Aman & & Boro & Aus & Aman & \\
\hline 2020 & 14.24 & 1.93 & 9.38 & 25.55 & 6.94 & 1.38 & 5.71 & 14.03 & 6.41 & 0.94 & 3.90 & 11.25 \\
\hline 2030 & 16.78 & 2.05 & 10.50 & 29.33 & 8.17 & 1.47 & 6.36 & 16.00 & 7.55 & 1.01 & 4.35 & 12.91 \\
\hline 2050 & 23.08 & 2.50 & 13.00 & 38.58 & 11.20 & 1.79 & 7.90 & 20.89 & 10.40 & 1.23 & 5.39 & 17.02 \\
\hline
\end{tabular}

Source: Authors' calculation based on Ministry of Agriculture and Bangladesh Bureau of Statistics, 2012 
Table 7. Requirement of fertiliser on the basis of actual dose (on average rice production data).

\begin{tabular}{|c|c|c|c|c|c|c|c|c|c|c|c|c|}
\hline \multirow{2}{*}{ Year } & \multicolumn{3}{|c|}{$\begin{array}{l}\text { Urea fertiliser } \\
\text { requirement (lakh tons) }\end{array}$} & \multirow{2}{*}{$\begin{array}{l}\text { Total } \\
\text { (lakh tons) }\end{array}$} & \multicolumn{3}{|c|}{$\begin{array}{l}\text { TSP fertiliser } \\
\text { requirement (lakh tons) }\end{array}$} & \multirow{2}{*}{$\begin{array}{l}\text { Total } \\
\text { (lakh tons) }\end{array}$} & \multicolumn{3}{|c|}{$\begin{array}{l}\text { MP fertiliser requirement } \\
\text { (lakh tons) }\end{array}$} & \multirow{2}{*}{$\begin{array}{l}\text { Total } \\
\text { (lakh tons) }\end{array}$} \\
\hline & Boro & Aus & Aman & & Boro & Aus & Aman & & Boro & Aus & Aman & \\
\hline 2007 & 7.37 & 1.52 & 7.57 & 16.46 & 1.81 & 0.31 & 1.68 & 3.80 & 1.42 & 0.19 & 1.35 & 2.96 \\
\hline 2020 & 8.96 & 1.84 & 9.20 & 20.00 & 2.19 & 0.38 & 2.04 & 4.61 & 1.73 & 0.23 & 1.64 & 3.60 \\
\hline 2030 & 10.30 & 2.12 & 10.60 & 23.02 & 2.52 & 0.44 & 2.35 & 5.31 & 1.98 & 0.27 & 1.88 & 4.13 \\
\hline 2040 & 11.83 & 2.43 & 12.10 & 26.36 & 2.9 & 0.50 & 2.70 & 6.10 & 2.28 & 0.31 & 2.16 & 4.75 \\
\hline 2050 & 13.60 & 2.80 & 14.00 & 30.40 & 3.33 & 0.58 & 3.10 & 7.01 & 2.62 & 0.35 & 2.48 & 5.45 \\
\hline
\end{tabular}

Source: Authors' calculation based on Ministry of Agriculture and Bangladesh Bureau of Statistics, 2012

Table 8. Requirement of fertiliser on the basis of actual dose (on changing conditions).

\begin{tabular}{|c|c|c|c|c|c|c|c|c|c|c|c|c|}
\hline \multirow{2}{*}{ Year } & \multicolumn{3}{|c|}{$\begin{array}{l}\text { Urea fertiliser } \\
\text { requirement (lakh tons) }\end{array}$} & \multirow{2}{*}{$\begin{array}{l}\text { Total } \\
\text { (lakh tons) }\end{array}$} & \multicolumn{3}{|c|}{$\begin{array}{l}\text { TSP fertiliser } \\
\text { requirement (lakh tons) }\end{array}$} & \multirow{2}{*}{$\begin{array}{l}\text { Total } \\
\text { (lakh tons) }\end{array}$} & \multicolumn{3}{|c|}{$\begin{array}{l}\text { MP fertiliser requirement } \\
\text { (lakh tons) }\end{array}$} & \multirow{2}{*}{$\begin{array}{l}\text { Total } \\
\text { (lakh tons) }\end{array}$} \\
\hline & Boro & Aus & Aman & & Boro & Aus & Aman & & Boro & Aus & Aman & \\
\hline 2007 & 7.37 & 1.52 & 7.57 & 16.46 & 1.81 & 0.31 & 1.68 & 3.8 & 1.42 & 0.19 & 1.35 & 2.96 \\
\hline 2020 & 10.17 & 1.84 & 7.63 & 19.64 & 2.49 & 0.38 & 1.7 & 4.57 & 1.96 & 0.23 & 1.36 & 3.55 \\
\hline 2030 & 11.98 & 1.97 & 8.51 & 22.46 & 2.93 & 0.41 & 1.89 & 5.23 & 2.31 & 0.25 & 1.51 & 4.07 \\
\hline 2040 & 13.99 & 2.26 & 9.48 & 25.73 & 3.43 & 0.47 & 2.11 & 6.01 & 2.7 & 0.28 & 1.69 & 4.67 \\
\hline 2050 & 16.47 & 2.4 & 10.6 & 29.47 & 4.03 & 0.5 & 2.35 & 6.88 & 3.17 & 0.3 & 1.88 & 5.35 \\
\hline
\end{tabular}

Source: Authors' calculation based on Ministry of Agriculture and Bangladesh Bureau of Statistics, 2012

\section{Importance of Organic Fertiliser}

The fertility status of the soil in Bangladesh is extremely variable, having differences in thirty agro-ecological zones, each of which has specific soil and hydrological characteristics. Soils deplete and decline after crop yields, if proper fertility management is not in place. Organic fertilisers can play a vital role in restoring fertility as well as organic material composition of cultivable soils. Organic matter content in soil is found to be very low, around 1 percent in most of the soils and 2 percent in paltry amount of soils, whereas at least 3 percent is conducive for high crop productivity [28].

Bioslurryl is one of the best organic fertilisers to rejuvenate soils since it is a rich source of both plant nutrients and organic matter. It increases physical, chemical and biological properties of soils, besides supplying essential nutrients to crop plants. It also increases organic matter content of soils and maintains health of soil. The use of bioslurry can reduce application of chemical fertilisers up to 50 percent [28]. Reduced uses of chemical fertilisers will also benefit the peasant farmers in terms of costs for cultivation in a soil environment of high fertility and productive state [29], [30].

In Bangladesh about 7 million tons of organic fertilisers are produced in every year from animal wastes, household wastes, city wastes and crop wastes [31], [32]. If this huge amount of organic fertilisers could be converted into bioslurry, a significant part of fertiliser demand could be fulfilled. If 7 million tons of organic fertiliser can be used in crop production, it could cover 5.3 percent of Urea, 19 percent of TSP and 34.13 percent of MP of the total demand of fertiliser

1 Bioslurry obtained from biogas plant is considered as quality organic fertiliser. This organic fertiliser is environmental friendly, has no toxic or harmful effects. Cow dung, poultry litter, compost, crop residues and green manure are commonly used in biogas plant. in FY 2008-09. Consequently, if the total organic fertiliser is used as a bioslurry, it could cover 11 percent demand of Urea, 89 percent TSP and 22.8 percent MP for the same period.

Table 9. Nutrient concentrations in commonly used organic fertilisers and bioslurry of Bangladesh.

\begin{tabular}{llll}
\hline \multirow{2}{*}{ Organic fertilisers } & \multicolumn{3}{c}{ Nutrient Content (percentage) } \\
\cline { 2 - 4 } & $\mathbf{N}$ & $\mathbf{P}$ & $\mathbf{K}$ \\
\hline Cow dung & $0.51-1.5$ & 0.40 .8 & 0.519 \\
Poultry manure & 1.6 & 1.5 & 0.85 \\
Compost (common) & 0.40 .8 & 0.30 .6 & 0.71 .0 \\
Farmyard manure & 0.51 .5 & 0.40 .8 & 0.511 .9 \\
Water hyacinth compost & 3.0 & 2.0 & 3.0 \\
Bioslurry (cow dung) & 1.29 & 2.80 & 0.75 \\
Bioslurry (Poultry litter) & 2.73 & 3.30 & 0.80 \\
Rice straw & 0.52 & 0.25 & 1.20 \\
Wheat straw & 0.63 & 0.28 & 0.80 \\
Maize stove & 0.45 & 0.30 & 0.70 \\
Sugarcane trash & 0.35 & 0.25 & 0.80 \\
Tobacco stems & 0.42 & 0.25 & 1.10 \\
\hline
\end{tabular}

Source: Islam, 2006

The contribution of organic fertilisers, therefore, may be significant if it is used as a bioslurry fertiliser. If it is possible to increase the application of organic fertilisers only by three times (21 million tons) to the present situation, it would contribute a large amount of nutrient supply to the soil for rice production (Table 11 and 12). From this basis, on average organic fertilisers may contribute more than 15 percent to the total demand of Urea, TSP and MP fertilisers. Moreover, while used as bioslurry fertilisers, it would contribute more than 30 of nutrient supply (N, P and K) for the rice production in (calculation is based on recommended dose). Considering the actual dose in field level, organic fertilisers would contribute more than 35 percent to the total demand of Urea, TSP and MP fertilisers. Whenever it is used 
as bioslurry fertilisers, it would contribute more than 85 of nutrient supply in the same period.

Table 10. Contribution of organic fertilisers to the total fertiliser demand in the FY 2008-09.

\begin{tabular}{llllll}
\hline Fertilisers & $\begin{array}{l}\text { Demand } \\
\text { (Lakh tons) }\end{array}$ & $\begin{array}{l}\text { Contribution of organic } \\
\text { fertiliser (Lakh tons) }\end{array}$ & $\begin{array}{l}\text { Contribution of bioslurry } \\
\text { fertiliser (Lakh tons) }\end{array}$ & $\begin{array}{l}\text { Percentage of total demand } \\
\text { (organic fertiliser) }\end{array}$ & $\begin{array}{l}\text { Percentage of total demand } \\
\text { (bioslurry fertiliser) }\end{array}$ \\
\hline Urea & 28.5 & 1.50 & 3.13 & 5.30 & 11 \\
TSP & 5.0 & 0.95 & 4.45 & 19.00 & 89 \\
MP & 4.0 & 1.37 & 0.91 & 34.13 & 22.8 \\
\hline
\end{tabular}

Source: Authors' calculation based on the nutrient concentrations in commonly used organic fertilisers and bioslurry of Bangladesh, 2012

Table 11. Contribution of organic and bioslurry fertilisers for rice production in 2050 (calculation based on recommended dose).

\begin{tabular}{lllllllllll}
\hline & \multicolumn{2}{l}{ Based upon Average Condition } & \multicolumn{5}{c}{ Based upon Changing Condition } \\
Fertilisers & $\begin{array}{l}\text { Demand } \\
\text { (Lakh } \\
\text { tons) }\end{array}$ & $\begin{array}{l}\text { Contribution } \\
\text { of organic } \\
\text { fertiliser } \\
\text { (Lakh tons) }\end{array}$ & $\begin{array}{l}\text { Contribution } \\
\text { of bioslurry } \\
\text { fertiliser } \\
\text { (Lakh tons) }\end{array}$ & $\begin{array}{l}\text { Percentage } \\
\text { of total } \\
\text { demand } \\
\text { (organic } \\
\text { fertiliser) }\end{array}$ & $\begin{array}{l}\text { Percentage } \\
\text { of total } \\
\text { demand } \\
\text { (bioslurry } \\
\text { fertiliser) }\end{array}$ & $\begin{array}{l}\text { Demand } \\
\text { (Lakh } \\
\text { tons) }\end{array}$ & $\begin{array}{l}\text { Contribution } \\
\text { of organic } \\
\text { fertiliser } \\
\text { (Lakh tons) }\end{array}$ & $\begin{array}{l}\text { Contribution } \\
\text { of bioslurry } \\
\text { fertiliser } \\
\text { (Lakh tons) }\end{array}$ & $\begin{array}{l}\text { Percentage } \\
\text { of total } \\
\text { demand } \\
\text { (organic } \\
\text { fertiliser) }\end{array}$ & $\begin{array}{l}\text { Percentage of } \\
\text { total demand } \\
\text { (bioslurry } \\
\text { fertiliser) }\end{array}$ \\
\hline Urea & 39.17 & 4.50 & 9.40 & 11.50 & 23.97 & 38.58 & 4.50 & 9.40 & 11.66 & 24.36 \\
TSP & 21.77 & 2.85 & 13.35 & 13.10 & 51.32 & 20.89 & 2.85 & 13.35 & 13.64 & 63.91 \\
MP & 17.13 & 4.10 & 2.73 & 24.00 & 17.02 & 17.02 & 4.10 & 2.73 & 24.10 & 16.04 \\
\hline
\end{tabular}

Source: Authors' calculation based on the nutrient concentrations in commonly used organic fertilisers and bioslurry of Bangladesh, Ministry of Agriculture and Bangladesh Bureau of Statistics, 2012

Table 12. Contribution of organic and bioslurry fertilisers for rice production in 2050 (calculation based on actual dose).

\begin{tabular}{|c|c|c|c|c|c|c|c|c|c|c|}
\hline \multirow[b]{2}{*}{ Fertilisers } & \multicolumn{5}{|c|}{ Based upon Average Condition } & \multicolumn{5}{|c|}{ Based upon Changing Condition } \\
\hline & $\begin{array}{l}\text { Demand } \\
\text { (Lakh } \\
\text { tons) }\end{array}$ & $\begin{array}{l}\text { Contribution } \\
\text { of organic } \\
\text { fertiliser } \\
\text { (Lakh tons) }\end{array}$ & $\begin{array}{l}\text { Contribution } \\
\text { of bioslurry } \\
\text { fertiliser } \\
\text { (Lakh tons) }\end{array}$ & $\begin{array}{l}\text { Percentage } \\
\text { of total } \\
\text { demand } \\
\text { (organic } \\
\text { fertiliser) }\end{array}$ & $\begin{array}{l}\text { Percentage } \\
\text { of total } \\
\text { demand } \\
\text { (bioslurry } \\
\text { fertiliser) }\end{array}$ & $\begin{array}{l}\text { Demand } \\
\text { (Lakh } \\
\text { tons) }\end{array}$ & $\begin{array}{l}\text { Contribution } \\
\text { of organic } \\
\text { fertiliser } \\
\text { (Lakh tons) }\end{array}$ & $\begin{array}{l}\text { Contribution } \\
\text { of bioslurry } \\
\text { fertiliser } \\
\text { (Lakh tons) }\end{array}$ & $\begin{array}{l}\text { Percentage } \\
\text { of total } \\
\text { demand } \\
\text { (organic } \\
\text { fertiliser) }\end{array}$ & $\begin{array}{l}\text { Percentage } \\
\text { of total } \\
\text { demand } \\
\text { (bioslurry } \\
\text { fertiliser) }\end{array}$ \\
\hline Urea & 30.40 & 4.50 & 9.40 & 14.80 & 30.92 & 29.47 & 4.50 & 9.40 & 15.27 & 31.90 \\
\hline TSP & 7.01 & 2.85 & 13.35 & 40.00 & 190.44 & 6.88 & 2.85 & 13.35 & 4.42 & 194.04 \\
\hline MP & 5.45 & 4.10 & 2.73 & 75.23 & 50.10 & 5.35 & 4.10 & 2.73 & 76.64 & 51.03 \\
\hline
\end{tabular}

Source: Authors' calculation based on the nutrient concentrations in commonly used organic fertilisers and bioslurry of Bangladesh, Ministry of Agriculture and Bangladesh Bureau of Statistics, 2012

\section{Conclusion and Discussion}

The sustainable increase of crop production for food sufficiency requires efforts to enhance the capacity of production system. All agricultural inputs involved directly or indirectly in crop production need to be adequate and accessible at farmers' field level during the growing season. Timely supply and availability of fertilisers at reasonable prices at the doorsteps of the hard working farmers in the country is necessary for optimum supply of nutrients to the depleted soils, for successful achievement of the targeted yield.

According to the study, a linear correlation is there among the fertiliser application, the cropping intensity and high yielding varieties. In 2008-09, high yielding varieties covered more than 72 percent of the total cultivable land areas in Bangladesh. Similarly, cropping intensity has increased dramatically in the last decades and increased more than 23 percent in the last 15 years.

The study also suggests that the demand of chemical fertilisers have become significant which has a negative impact on soil fertility as well as sustainability of crop production. In 1985-86, fertiliser has contributed 36 percent to the total soil fertility whereas in 2002-07, this contribution was 40 percent. Thus, the increasing response of fertilisers over the time indicates the degradation of soil fertility. Therefore, it is urgent to conserve and add nutrients to the soil through the balance application of compost and inorganic fertilsers, which can help, maintain and increase the nutrient reserves of the soil.

Moreover, the prices of the imported fertilisers will continue to increase in the upcoming years due to high price of oil in internal market, and shrinking natural resources for fertiliser production. Therefore, mobilisation of all organic resources and recycling them into soil fertilisation programme can be considered. Besides, government can take some public awareness through media activities and advocacy to influence farmers in using balanced dose of fertiliser and can emphasise on the use of organic fertiliser for a sustainable rice production.

\section{Acknowledgement}

The authors would like to thank Dr. Jiban Krishan Biswas 
and Md. Abdus Salam of Bangladesh Rice Research Institute (BRRI) for their kind supports throughout this study. We are grateful to A. Z. M. Saleh of Unnayan Onneshan for valuable inputs during this study. A version of this research has earlier been published by the Unnayan Onneshan.

\section{References}

[1] Earth Summit, Policy on agriculture in sustainable development.1992. Available at: http://www.nda.agric.za/docs/Policy/SustainableDev.pdf

[2] EPBS. The Provincial Statistical Board and Bureau of Commercial Industrial Intelligence. Statistical Abstract for East Pakistan, Dacca, 1958, p 517.

[3] R. Ahmed, "Structure, dynamics and related policy issues of fertiliser subsidy in Bangladesh”. 1987, pp 281-380.

[4] M. A. Quasem, "Fertiliser use in Bangladesh: 1965-66 to 1975-76". Bangladesh Institute of Development Studies, Dhaka, 1978, p 37. (BIDS Research Report Series No. 25).

[5] J. K. Basak, "Future Fertiliser Demand for Sustaining Rice Production in Bangladesh: A Quantitative Analysis". Unnayan Onneshan-The Innovators, Dhaka, Bangladesh, 2010.

[6] K. L. Hossain, M. A. Wadud, and E. Santosa, "Effect of Tree Litter Application on Lowland Rice Yield in Bangladesh". Bul. Agron. vol.35, no.3, 2007.

[7] S. R. Osmani, and M. A. Quasem, "Pricing and Subsidy Policies for Bangladesh Agriculture". Research Monograph: 11, Bangladesh Institute of Development Studies, Dhaka, 1990 .

[8] S. Rahman, and G.B. Thapa, "Environmental impacts of technological change in Bangladesh agriculture: farmers' perceptions and empirical evidence". Outlook on Agriculture, vol.28, no.4, 1999, pp. 233-238.

[9] S. M. A. Hossain, and M. A. Kashem, "Agronomic management to combat declining soil fertility in Bangladesh". Paper presented in the 6th Biennial Conference of the Bangladesh Society of Agronomy, held on 29 July 1997 in Dhaka.

[10] A. M. S. Ali, "Population pressure, environmental constraints and agricultural changes in Bangladesh: examples from three agro ecosystems". Agric. Ecosyst. Environ vol.55, 1995, pp. 95-109.

[11] S. Pagiola, "Environmental and Natural Resource Degradation in Intensive Agriculture in Bangladesh". Document of Agriculture and Natural Resource Operations Division, South Asia Region, World Bank, Washington, DC, 1995.

[12] K. Ahmad, and S. M. Q. Hasanuzzaman, "Agricultural Growth and Environment”. In: Faruquee, R.(Ed.), Bangladesh Agriculture in the 21 st Century. University Press Ltd, Dhaka, 1998.

[13] S. M. A. Hossain, M. U. Salam, and A. B. M. M. Alam, "Farm environment assessment in the context of farming systems in Bangladesh". Paper presented in the Third Asian Farming Systems Symposium on 7-10 November 1994, in Manila.
[14] M. Asaduzzaman, "Resource degradation and sustainable development in Bangladesh: some preliminary estimates". Paper presented in seminar on planning for sustainable development of Bangladesh, held on 24-25 Sept., 1996 in Dhaka.

[15] A.A. K. M. Quader, "Strategy for Developing the Fertilizer Sector in Bangladesh for Sustainable Agriculture". Chemical Engineering Research Bulletin 13, 2009, 39-46.

[16] S. Z. Rashid, "Composting and Use of Compost for Organic Agriculture in Bangladesh". Proceedings of the 4th International Conference for the Development of Integrated Pest Management in Asia and Africa, 20-22 January 2011.

[17] Ministry of Finance. Bangladesh Economics Review. Finance Division, Government of the Peoples' Republic of Bangladesh. Dhaka, Bangladesh, 2013.

[18] Ministry of Finance. Bangladesh Economics Review. Finance Division, Government of the Peoples' Republic of Bangladesh. Dhaka, Bangladesh, 2010.

[19] Ministry of Finance. Bangladesh Economics Review. Finance Division, Government of the Peoples' Republic of Bangladesh. Dhaka, Bangladesh, 2009.

[20] Bangladesh Bureau of Statistics (BBS). Statistical Year Book of Bangladesh. Planning Division, Ministry of Planning, Government of the People's Republic of Bangladesh, 2012.

[21] Bangladesh Bureau of Statistics (BBS). Statistical Year Book of Bangladesh. Planning Division, Ministry of Planning, Government of the People's Republic of Bangladesh, 2007.

[22] S. K. De Datta, "Principles and practices of rice production". International Rice Research Institute. Los Banos, Philippines. 1981.

[23] O. C. Bockman, O. Kaarstard, O.H. and I. Richards, "Agriculture and fertilizers". Agriculture group, Norsk Hydro a.s. Osl, Norway, 1990.

[24] H L S. Tandon, "Fertiliser Guide for Extension Workers, Sales personnel, Studies, Laboratories, Dealers and Farmers". FDCO, New Delhi, India, 1992, p 158.

[25] A. L. Shah, M.S. Rahman, and M.A. Aziz, "Outlook for fertiliser consumption and food production in Bangladesh". Bangladesh I.Agric. and Environ. vol.4, 2008, pp.1-8.

[26] R. A. M. Titumir, and J. K. Basak, "A Long Run Perspective on Food Security and Sustainable Agriculture in South Asia". Dhaka University, Journal of Development Studies, vol. 1, no. $1,2010$.

[27] Food and Agriculture Organisation (FAO), Food and Agriculture Organisation of The United Nations Statistics Division. 2009. Available at: http://faostat.fao.org/default.aspx

[28] M.S. Islam, "Use of Bioslurry as Organic Fertiliser in Bangladesh Agriculture". Prepared for the presentation at the International Workshop on the Use of Bioslurry Domestic Biogas Programme. Bangkok, Thailand, 2006.

[29] M. Hossain, "Fertiliser consumption, pricing and food grain production in Bangladesh". In: 1987. Fertiliser pricing policy in Bangladesh (Bruce Stone, ed.). IFPRI, Washington D.C. 1987.

[30] S. M. H. Zaman, "Agronomic and environmental constraints in fertiliser effectiveness". In: Fertiliser pricing policy in Bangladesh (Bruce Stone, ed.). IFPRI, Washington D.C, 1987. 
[31] A. Razzak, "Production Status of Organic Manure in Bangladesh". Department of Livestock Services, Dhaka, Bangladesh, 2006.
[32] S. Alam, "Production of organic manure in Bangladesh". Bangladesh Livestock Research Institute's Report, Savar, Dhaka, Bangladesh, 2006. 